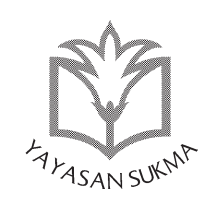

SUKMA: JURNAL PENDIDIKAN

ISSN: 2548-5105 (p), 2597-9590 (e) Volume 3 Issue 1, Jan-Jun 2019, pp. 35-56 https://doi.org/10.32533/03103.2019 www.jurnalsukma.org

\title{
HUBUNGAN ANTARA MOTIVASI BELAJAR DAN COOPERATIVE LEARNING TERHADAP PRESTASI BELAJAR DI SD MUHAMMADIYAH SOKONANDI YOGYAKARTA
}

\section{Wasito}

Universitas Ahmad Dahlan Yogyakarta, Indonesia email: toshe83@yahoo.co.id

\begin{abstract}
Abstrak
Motivasi dan penerapan metode belajar dalam pembelajaran dapat membantu banyak hal diantaranya berpengaruh pada prestasi belajar siswa. Salah satu metode tersebut adalah metode kooperatif. Metode ini merupakan suatu metode yang menggunakan pendekatan komunikatif dalam bentuk kelompok-kelompok kecil,yang terdiri antara 4-5 orang dalam setiap kelompok. Tujuan Penelitian ini adalah untuk menguji apakah ada pengaruh metode pembelajaran kooperatif (cooperative learning) dan motivasi belajar terhadap prestasi belajar siswa Sekolah Dasar. Hipotesis dalam
\end{abstract}


penelitian ini adalah bahwa motivasi belajar dan pembelajaran kooperatif berperan positif terhadap prestasi belajar. Subjek penelitian adalah 38 siswa kelas IV di Sekolah Dasar Muhammadiyah Sokonandi Yogyakarta, yang terdiri dari 17 laki-laki dan 21 perempuan. Hasil penelitian berdasarkan analisis regresi 2 prediktor, nilai koefisien korelasi $(R)$ dikonversi dalam nilai $F$ sebesar 0.225 dengan $p=0.799$ ( $p>0.05)$, hasilnya menunjukkan bahwasannya tidak ada hubungan antara motivasi belajar dan pembelajaran kooperatif terhadap prestasi belajar siswa. Sehingga dapat dikatakan bahwa prestasi belajar tidak dapat diprediksi dari motivasi belajar dan metode pembelajaran kooperatif. Dengan kata lain, siswa yang mempunyai motivasi belajar dengan metode belajar kooperatif tidak dapat meningkatkan atau menurunkan prestasi belajar.

Kata Kunci: metode cooperative learning, critical thinking, social interaction, motivasi belajar, prestasi belajar

\section{A. Pendahuluan}

Paradigma lama tentang proses pembelajaran yang bersumber pada teori tabula rasa John Lock di mana pikiran seorang anak seperti kertas kosong dan siap menunggu coretan-coretan dari gurunya sepertinya kurang tepat lagi digunakan oleh para pendidik saat ini. Tuntutan pendidikan sudah banyak berubah. Pendidik perlu menyusun dan melaksanakan kegiatan belajar mengajar di mana anak dapat aktif membangun pengetahuannya sendiri. Hal ini sesuai dengan pandangan konstruktivisme yaitu keberhasilan belajar tidak hanya bergantung pada lingkungan atau kondisi belajar, tetapi juga pada pengetahuan awal siswa. Belajar melibatkan pembentukan "makna" oleh siswa dari apa yang mereka lakukan, lihat dan dengar. Pembelajaran kooperatif merupakan salah satu pembelajaran yang dikembangkan dari teori kontruktivisme karena mengembangkan struktur kognitif 
untuk membangun pengetahuan sendiri melalui berpikir rasional (Santrock 2007).

Metode pembelajaran yang hanya meneruskan pengetahuan, the sage on the stage, tidak memberikan peluang kepada pembelajar berinteraksi dan bertransaksi antar pembelajar menyebabkan mereka kehilangan waktunya untuk mengartikulasikan pengalaman belajar. Pembelajaran yang memberikan latihan berpikir kritis (critical thinking) dan interaksi sosial (social interaction) hanya mendapatkkan porsi waktu yang sangat sedikit karena guru hanya disibukkan dengan tugas rutinitas untuk segera menuntaskan kurikulum yang menjadi tanggung jawabnya. Proses pembelajaran perlu memperhatikan penanaman aspek-aspek soft skills, yang antara lain kerja sama dalam belajar, rasa saling menghargai pendapat, rasa saling memiliki (sense of belonging), rasa tanggung jawab (sense of responsibility), kejujuran dan rela berkorban dan seterusnya yang saat ini terasa diabaikan dan masih belum memperoleh perhatian besar dalam dunia pendidikan kita. Nampaknya, sekolah-sekolah hanya mengajarkan pengetahuan kognitif demi mengejar nilai baik saja agar supaya mereka, para pembelajar, lulus ujian dan mengabaikan keseimbangan perkembangan dimensi-dimensi afektif dan psikomotorik.

Metode kooperatif adalah salah satu metode belajar mengajar yang menggunakan pendekatan komunikatif dalam bentuk kelompok-kelompok kecil, yaitu hanya terdiri antara 4-5 orang dalam setiap kelompok. Metode yang sangat menekankan unsur kolaboratif, komunikatif dan kooperatif yang kuat ini memiliki manfaat seperti yang diharapkan oleh pendekatan komunikatif yaitu untuk menumbuhkan motivasi belajar siswa (Slavin 1991). Kerjasama dalam kelompok kecil tersebut melibatkan aspek afektif, sehingga akan menumbulkan kecintaan siswa kepada mata pelajaran yang diberikan (Mahmud 1990).

Belajar kooperatif memiliki unsur kerjasama yang kuat dan kooperatif dalam kelompok sekaligus unsur kompetisi antar kelompok, sekalipun unsur kooperasinyajauh lebih banyak diban- 
dingkan dengan unsur kompetisinya. Menurut konsep psikologi humanistik, sistem kerja sama dan berkompetisi secara sehat merupakan aspek humanisasi yang bersifat asasi pada diri setiap individu (Slavin 1991). Pembelajaran kooperatif dapat berjalan dengan baik apabila terdapat motivasi belajar dalam diri siswa, karena motivasi merupakan suatu proses untuk membangkitkan, mempertahankan dan mengontrol bagaimana siswa-siswi dapat menguasai pelajaran yang diberikan oleh guru.

Pembelajaran kooperatif dapat meningkatkan motivasi belajar dimana terdapat siswa yang belum memahami pelajaran-pelajaran akan merasa terbantu untuk belajar bersama dengan teman-temannya yang memahami pelajaran tersebut. Menurut McDonald dalam Hamalik (2007), "motivation is an energy change within the person characterized by affective arousal and anticipatory goal reactions". Motivasi adalah suatu energi perubahan dalam pribadi seseorang yang ditandai dengan timbulnya semangat afektif dan reaksi yang antisipatif terhadap tujuan. Artinya ketika siswa yang merasa terbantu dengan pembelajaran kooperatif ini akan termotivasi untuk menyelesaikan tugas yang diberikan oleh guru.

Berdasarkan uraian di atas dapat diketahui bahwa motivasi belajar dan pembelajaran kooperatif dapat meningkatkan prestasi belajar siswa. Dengan demikian permasalahan yang dapat dirumuskan adalah: Bagaimana hubungan motivasi belajar dan pembelajaran kooperatif terhadap prestasi belajar? Sedangkan tujun dari penelitian ini adalah untuk mengetahui hubungan motivasi belajar dan pembelajaran kooperatif terhadap prestasi belajar siswa di SD Muhammadiyah Sokonandi Yogyakarta.

\section{B. Pengertian Motivasi Belajar}

Motivasi merupakan keadaan dalam diri individu atau organisme yang mendorong perilaku ke arah tujuan (Walgito 2002). Ditambahkan De Coco dan Crowford (1977), bahwa motivasi mengacu pada faktor-faktor yang dapat meningkatkan dan mengurangi kekuatan atau kegiatan dalam suatu aktivi- 
tas individu. Sukmadinata (2007), menyatakan pada dasarnya pengertian motivasi menyangkut tiga hal pokok yaitu adanya dorongan, kegiatan atau proses pelaksanaannya, dan tujuan yang hendak dicapai. Dari ketiga hal tersebut dapat dirumuskn mengenai tiga pertanyaan mengenai perilaku individu yaitu apa (what), bagaimana (how), dan mengapa (why). Pertanyaan apa menanyakan tentang apa yang mendorong individu melakukan sesuatu hal (motif). Pertanyaan bagaimana mengacu pada bagaimana individu melakukan atau melaksanakan dorongan tersebut (kegiatan). Pertanyaan mengapa yaitu alasan individu melakukan sesuatu (tujuan).

Menurut Huitt (2001), definisi berikut motivasi yang dikumpulkan dari berbagai buku pelajaran psikologi dan mencerminkan konsensus umum bahwa motivasi adalah keadaan atau kondisi internal (kadang-kadang digambarkan sebagai kebutuhan, keinginan, atau ingin) yang berfungsi untuk mengaktifkan energi untuk menghasilkan perilaku dan memberikan arah (www.edpsycinteractive.org).

De Coco dan Crowford (1977) menyebut motivasi dalam bidang pendidikan disebut sebagai effort, maka motivasi dalam proses belajar sangat dibutuhkan karena dalam proses belajar itu sendiri yang sangat berperan penting adalah sejauh mana individu dapat membangkitkan motivasi belajarnya dan sejauhmana individu dapat mengerahkan segala usaha belajarnya. Menurut Djamarah (2002), motivasi pada setiap individu berbeda-beda karena setiap individu memiliki tujuan belajar yang berbeda pula, ada yang sekedar ingin menghindari nilai yang jelek bahkan hukuman dari guru, sehingga orientasinya hanya untuk memperoleh nilai yang tinggi, dan ada pula yang memang benar-benar ingin mengembangkan wawasan dan pengetahuannya.

Kauchak dan Eggen (1997) mengemukakan bahwa motivasi belajar dapat dilihat dari sejauh mana siswa mempunyai perhatian terhadap suatu pelajaran, mengajukan banyak pertanyaan dan keinginan untuk belajar. Motivasi murid secara alami ada 
hubungannya dengan keinginan siswa untuk berpartisipasi dalam proses belajar. Tetapi juga berkaitan dengan alasan atau tujuan yang mendasari keterlibatan mereka atau non keterlibatan dalam kegiatan akademik. Walaupun sama-sama siswa dapat termotivasi untuk melakukan tugas, sumber motivasi mereka mungkin berbeda.

\section{Aspek-aspek Motivasi Belajar}

Menurut McCown et al (1997) menyatakan bahwa untuk mengetahui tingkat motivasi siswa dalam kegiatan belajar dapat diamati melaui tiga aspek, yaitu:

a) Keinginan dan inisiatif sendiri untuk belajar. Keinginan atau inisiatif untuk belajar merupakan kekuatan atau energy dalam diri individu atau siswa yang bersangkutan.

b) Keterlibatan yang ditandai dengan kesungguhan mengerjakan tugas yang diberikan. Keterlibatan dalam mengerjakan tugas sebagai wujud interaksi antara kekuatan internal individu dengan situasi dari luar individu (eksternal).

c) Komitmen untuk terus belajar. Orang yang memiliki komitmen dan keyakinan yang kuat untuk belajar akan memiliki motivasi belajar yang cukup tinggi.

Sedangkan menurut Monique Boekaerts dalam www.ibe. unesco.org, di dalam kelas tertutup konten dan konteks sosial terus bervariasi. Oleh karena itu, anak-anak sering terlibat dalam situasi belajar yang asing. Hal ini dapat menciptakan ambiguitas dan ketidakpastian untuk beberapa murid dan tantangan bagi siswa lain. Siswa mencoba memahami situasi pembelajaran novel dengan mengacu keyakinan motivasi mereka. Keyakinan motivasi mengacu kepada pendapat, penilaian dan nilai-nilai siswa yang dipegang tentang objek, peristiwa atau subjek-materi domain. Peneliti menggambarkan keyakinan bahwa siswa menggunakan pemberian makna pada situasi belajar. Keyakinan terhadap motivasi juga mengacu pada pendapat siswa tentang efisiensi atau efektivitas belajar dan metode pengajaran, banyak penelitian telah menunjukkan bahwa hasil dari keyakinan motivasi 
pengalaman belajar langsung (misalnya Sandra: "Kebanyakan soal matematika terlalu sulit bagi saya untuk mendapatkan hak mereka pertama kali. Akan tetapi, ketika seseorang memberi saya petunjuk saya bisa memecahkan banyak masalah") adalah hal yang menjadi aspek timbulnya keyakinan motivasi itu sendiri.

Keyakinan yang menimbulkan motivasi bertindak sebagai kerangka acuan yang memandu siswa berpikir, perasaan dan tindakan dalam sebuah wilayah subjek. Misalnya, keyakinan motivasi tentang matematika menentukan strategi berpikir siswa yang sesuai untuk melakukan tugas yang spesifik. Perlu dicatat bahwa seorang siswa berkeyakinan tentang sebuah domain mungkin akan dominan menguntungkan (optimistis) atau tidak menguntungkan (pesimis), sehingga menyediakan konteks positif atau negatif bagi belajar. Setelah terbentuk, motivasi menguntungkan dan tidak menguntungkan kepercayaan sangat resisten terhadap perubahan.

\section{Faktor-faktor yang Mempengaruhi Motivasi Belajar}

Suryabrata (1998) mengklasifikasikan faktor-faktor yang mempengaruhi motivasi belajar siswa berdasarkan dua factor, yaitu (a) faktor dari luar: (1) sosial, berasal dari individu yang ikut berperan penting dalam proses belajar seperti orangtua, guru dan teman dan (2) non-sosial, segala sesuatu yang berada di sekitar individu baik dalam wujud benda konkrit maupun abstrak seperti sarana, fasilitas belajar, suhu, cuaca; dan (b) faktor dari dalam: (1) fisiologis, keadaan jasmani individu secara umum seperti lapar, lelah, istirahat, serta sebagainya; dan (2) psikologis, dipengaruhi: sifat ingin tahu dan menyelidiki dunia yang lebih luas; sifat kreatif dan keinginan untuk selalu maju; keinginan untuk mendapatkan simpati dari orangtua, guru, dan teman; memperbaiki kegagalan yang lalu dengan usaha baru baik dengan kooperasi maupun dengan kompetisi; mendapatkan rasa aman bila menguasai pelajaran; adanya ganjaran atau hukuman.

Menurut Barbara Davis (http://honolulu.hawaii.edu)para peneliti telah mulai mengidentifikasi aspek-aspek dari situasi 
yang meningkatkan pengajaran siswa tentang motivasi diri. Untuk mendorong siswa menjadi mandiri dan pembelajar yang bermotivasi diri, instruktur dapat melakukan hal berikut: (a) berikan lebih sering, pada awal, umpan balik positif yang mendukung keyakinan siswa bahwa mereka dapat melakukan yang terbaik; (b) memastikan kesempatan bagi siswa sukses dengan menetapkan tugas-tugas yang tidak terlalu mudah juga tidak terlalu sulit; (c) membantu siswa menemukan makna dan nilai pribadi dalam materi; (d) ciptakan suasana yang terbuka dan positif; (e) membantu siswa merasa bahwa mereka dihargai anggota komunitas belajar.

Menurut W. Huitt (2001) (www.edpsycinteractive.org), sumber yang mempengaruhi kebutuhan dalam motivasi adalah (1) perilaku/eksternal: menimbulkan rangsangan yang terkait/ terhubung ke alam bawah rangsangan; memperoleh yang diinginkan, konsekuensi menyenangkan (imbalan) atau melarikan diri/menghindari yang tidak diinginkan, konsekuensi yang tidak menyenangkan; (2) social: meniru model positif; menjadi bagian dari sebuah kelompok atau anggota yang berharga; (3) biologis: meningkat/menurun stimulasi (rangsangan); mengaktifkan indera (rasa, sentuhan, bau, dll; memperkecil pengaruh rasa lapar, haus, ketidaknyamanan, dll; mempertahankan homeostasis, keseimbangan; (4) kognitif: mempertahankan perhatian pada sesuatu yang menarik atau mengancam; mengembangkan makna atau pemahaman; kenaikan/penurunan kognitif disekuilibrium, ketidakpastian; memecahkan masalah atau membuat keputusan; memikirkan sesuatu; menghilangkan ancaman atau risiko; (5) afektif: meningkat/menurun afektif disonansi; meningkatkan perasaan yang baik; menurunkan perasaan "badmood"; meningkatkan keamanan terhadap harga diri; mempertahankan tingkat optimisme dan antusiasme; (6) konatif: pertemuan secara individu dikembangkan; memperoleh mimpi pribadi; mengembangkan atau mempertahankan efektivitas diri; menghilangkan ancaman terhadap tujuan pertemuan, memperoleh mimpi; mengurangi orang lain mengendalikan kehidupan seseorang; (7) rohani: memahami tujuan hidup seseorang; menghubungkan 
diri ke akhir dari tujuan hidup.

\section{Prestasi Belajar}

Menurut Supriyono dan Ahmadi (1991) setiap orang yang memberikan pendidikan sudah tentu ingin mengetahui sejauhmana anak didik dapat menguasai bahan pelajaran yang dicapai oleh anak didik. Prestasi belajar adalah hasil yang dicapai oleh seseorang dalam usaha belajarnya atau dalam melkukan aktivitas belajarnya yang dinyatakan dalam bentuk angka atau huruf sebagai cerminan kemampuannya menyerap pelajaran yang diberikn di sekolah dalam jangka waktu tertentu (Hardjito 1994).

\section{Faktor-faktor yang Mempengaruhi Prestasi Belajar}

Menurut Purwanto dalam Ulfah (2017), terdapat dua faktor yang mempengaruhi prestasi belajar, yaitu:

a) Faktor luar, terdiri dari: (1) Enviromental input, yaitu lingkungan alam dan lingkungan sosial; dan (2) Instrumental Input yang terdiri dari lingkungan alam dan lingkungan sosial. Instrumental input terbagi pada kurikulum/bahan pelajaran, guru/staf pengajar, sarana dan fsilitas, dan administrasi/manajemen.

b) Faktor dalam. Faktor ini merupakan raw input siswa baik secara fisiologis maupun psikologis. Faktor dalam secara fisiologis meliputi kondisi fisik dan kondisi panca indera. Faktor dalam secara psikologis mencakup bakat, minat, kecerdasan, motivasi, dan kemampuan kognitif.

Sukmadinanta (2003) menyatakan bahwa faktor-faktor yang mempengaruhi usaha dan keberhasilan belajar terdiri dari (1) faktor dalam diri individu, menyangkut aspek jasmaniah maupun rohaniah, terdiri dari kondisi kesehaan psikis, kemampuan-kemampuan intelektual, sosial, psikomotor serta kondisi afektif dan konatif dari individu; serta (2) faktor luar individu menyangkut fisik mupun sosio-psikologis yang berada pada lingkungan keluarga, sekolah, dan masyarakat. 


\section{Cooperative Learning}

Sistem pembelajaran kooperatif atau cooperative learning merupakan sistem pengajaran yang memberi kesempatan kepada anak didik untuk bekerjasama dengan sesama siswa dalam tugas-tugas yang terstruktur. Pembelajaran kooperatif dikenal dengan pembelajaran secara berkelompok. Tetapi belajar kooperatif lebih dari sekedar belajar kelompok atau kerja kelompok karena dalam belajar kooperatif ada struktur dorongan atau tugas yang bersifat kooperatif sehingga memungkinkan terjadinya interaksi secara terbuka dan hubungan yang bersifat interdepedensi efektif diantara anggota kelompok (Sugandi 2002).

Kauchak and Eggen (1997), memberikan definisi mengenai belajar kooperatif yaitu suatu strategi pengajaran yang digunakan untuk membantu peserta didik menemukan tujuan belajarnya, baik secara personal maupun interpersonal yang disusun dalam suatu kelompok kecil.

\section{Karakteristik Belajar Kooperatif}

Johnson dan Slavin dalam Kauchak and Eggen (1997) mengisyaratkan bahwa untuk memperoleh hasil yang efektif, belajar kooperatif sebaiknya memenuhi empat kriteria: (a) ada ketergantungan secara positif antar anggota kelompok (positive interdependent), yaitu memiliki kegiatan yang disusun agar siswa memiliki ketergantungan dan kerjasama yang kuat untuk mencapai tujuan kelompok mereka dengan baik; (b) ada interaksi; saling berhadapan (face to face interaction) antar anggota kelompok; (c) pertanggungjawaban secara individu (individual accountability). Hal ini dimaksudkan untuk menjunjung salah satu tujuan belajar kooperatif yaitu meningkatkan kemampuan menyerap materi yang merupakan peningkatan kualitas belajar. Sehingga setiap anggota kelompok bertanggungajawab terhadap isi pelajaran yang diberikan; dan (d) keterampilan sosial yang mengarahkan siswa untuk berhubungan antar anggota yang tidak luput dari interaksi dan pemantauan guru. Keterampilan sosial ini terdiri atas keterampilan untuk menyatakan pendapat, belajar 
menghargai orang lain dan saling tolong menolong terutama jika ada teman yang merasa kesulitan untuk memahami materi yang telah diberikan.

Kauchak and Eggen (1997) menegaskan bahwa unsur-unsur yang penting dalam penerapan belajar kooperatif adalah (1) pengelompokkan (grouping). Sebaliknya juga anggota kelompok bervariasi, yaitu ada yang berkemampuan tinggi, sedang, dan rendah. Laki-laki dan perempuan, dan dari etnik yang berbeda; (2) tugas (learning task), baik tugas kelompok atau tugas individu dalam bentuk kuis atau daftar pertanyaan; (3) pelatihan (training); dan 4) monitoring oleh guru.

Mahmud (1990) menyatakan bahwa ada tiga karakteristik dalam belajar kooperatif, yaitu: (1) siswa bekerja dalam tim-tim belajar yang kecil (4-5 orang); (2) siswa didorong untuk saling membantu dalam mempelajari materi yang telah diberikan dan dalam tugas kelompok; (3) siswa diberi imbalan atau penghargaan atas segala prestasi yang diperoleh. Menurut Slavin dalam Mahmud (1990), menguraikan bahwa efektivitas pelaksanaan belajar kooperatif sebaiknya anggota kelompok terdiri dari 4 orang siswa yang meliputi : 1 orang siswa kurang (low achiever), 2 orang siswa sedang (average achiver), dan 1 orang siswa yang cerdas (high achiever) pada mata pelajaran yang berangkutan.

\section{Tipologi Cooperative Learning}

Metode pembelajaran alternative memiliki berbagai macam perbedaan, tetapi dapat dikategorisasikan menurut enam karakteristik prinsipil (E. Salvin 2009).

a) Tujuan kelompok. Kebanyakan metode pembelajaran koperatif menggunakan beberapa bentuk tujuan kelompok. Dalam metode pembelajaran tim siswa, ini bisa serupa sertifikat atau rekognisi lainnya yang diberikan kepada tim yang memenuhi criteria yang telah ditentukan sebelumnya; dalam metode johson, kelas kelompok sering kali diberikan.

b) Tanggung jawab individual. Ini dilaksanakan dalam dua cara. Yang pertama adalah dengan menjumlah skor kelompok 
atau nilai rata-rata kusi individual atau penilaian lainnya, seperti daam model pembelajaran siswa. Yang kedua adalah spesialisasi tugas, dimana tiap siswa diberikan tanggung jawab khusus untuk sebagian tugas kelompok.

c) Kesempatan sukses yang sama. Karakteristik unik dari metode pembelajaran tim siswa adalah penggunaan metode skor yang memastikan semua siswa mendapat kesempatan yang sama dalam timnya. Metode tersebut terdiri atas poin kemajuan (STAD), kompetensi dengan yang setara (TGT),

\begin{tabular}{|c|c|c|c|c|c|c|}
\hline Metode & 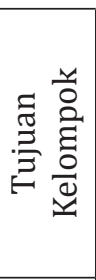 & 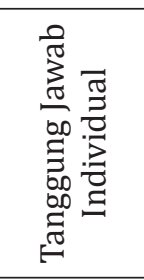 & 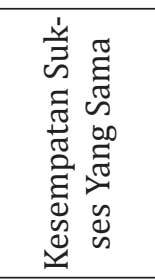 & 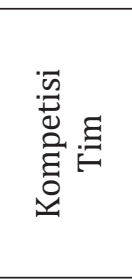 & 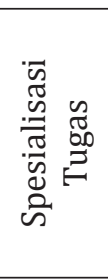 & 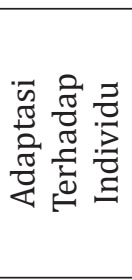 \\
\hline $\begin{array}{l}\text { Divisi } \\
\text { Pencapaian- } \\
\text { tim siswa }\end{array}$ & $\mathrm{Ya}$ & Ya & $\begin{array}{l}\text { Ya (Poin } \\
\text { perkem- } \\
\text { bangan) }\end{array}$ & $\begin{array}{l}\text { Kadang- } \\
\text { kadang }\end{array}$ & Tidak & Tidak \\
\hline $\begin{array}{l}\text { Tim game- } \\
\text { turnamen }\end{array}$ & $\mathrm{Ya}$ & Ya & $\begin{array}{c}\text { Ya } \\
\text { (system } \\
\text { turna- } \\
\text { men) }\end{array}$ & Ya & Tidak & Tidak \\
\hline $\begin{array}{l}\text { Individual- } \\
\text { isasi }\end{array}$ & $\mathrm{Ya}$ & Ya & $\begin{array}{l}\text { Ya (yang } \\
\text { individu- } \\
\text { alis) }\end{array}$ & Tidak & Tidak & Ya \\
\hline $\begin{array}{l}\text { Diawasi, } \\
\text { mengarang } \\
\text { \& membaca } \\
\text { terintregasi }\end{array}$ & $\mathrm{Ya}$ & $\mathrm{Ya}$ & $\begin{array}{l}\text { Ya (oleh } \\
\text { subyek } \\
\text { kelom- } \\
\text { pok) }\end{array}$ & Tidak & Tidak & $\mathrm{Ya}$ \\
\hline $\begin{array}{l}\text { Belajar } \\
\text { bersama }\end{array}$ & $\mathrm{Ya}$ & $\begin{array}{l}\text { Kadang- } \\
\text { kadang }\end{array}$ & Tidak & Tidak & Ya & Tidak \\
\hline Jigsaw I & $\mathrm{Ya}$ & $\begin{array}{l}\text { Ya (spe- } \\
\text { sialisasi } \\
\text { tugas) }\end{array}$ & Tidak & Tidak & Ya & Tidak \\
\hline Jigsaw II & $\mathrm{Ya}$ & $\begin{array}{l}\text { Ya (spe- } \\
\text { sialisasi } \\
\text { tugas) }\end{array}$ & $\begin{array}{l}\text { Ya (poin } \\
\text { perkem- } \\
\text { bangan) }\end{array}$ & Tidak & Ya & Tidak \\
\hline
\end{tabular}

Tabel 1: Tipologi Metode-metode Pembelajaran Koperatif 
atau adaptasi tugas terhadap tingkat kinerja individual (TAI dan CIRC).

d) Kompetisi tim. Studi tahap awal dari STAD dan TGT menggunakan kompetensi antar tim sebagai sarana untuk memotivasi siswa untuk bekerja sama dengan anggota timnya.

e) Spesialisasi tugas. Unsur utama dari Jigsaw, Group Investigation, dan metode spesialisasi tugas lainnya adalah tugas untuk melaksanakan subtugas terhadap masing-masing anggota kelompok.

f) Adaptasi terhadap kebutuhan kelompok. Kebanyakan metode pembelajaran koperatif menggunakan pengajaran yang mempercepat langkah kelompok, tetapi tetap mengadaptasi pengajaran terhadap kebutuhan individual.

\section{Metode-Metode Cooperative Learning}

a) Student Team-Achievement Divison (STAD). STAD merupakan salah satu metode pembelajaran kooperatif yang paling sederhana, dan merupakan model yang paling baik untuk permulaan bagi para guru yang baru menggunakan pendekatan kooperatif (Roberth E. Salvin, Cooperative Learning). Dalam STAD, para siswa dibagi dalam tim belajar yang terdiri atas empat orang yang berbeda-beda tingkat kemampuan, jenis kelamin, dan latar belakang etniknya. Guru yang menyampaikan pelajaran, lalu siswa bekerja dalam tim mereka untuk memastikan bahwa semua anggota tim telah menguasai pelajaran. Selajutnya semua siswa mengerjakan kuis mengenai materi secara sendiri-sendiri dimana saat itu mereka tidak diperbolehkan untuk saling bantu. STAD terdiri atas lima komponen utama. Pertama, presentasi kelas. Dalam presentasi dengan menggunakan STAD merupakan pengajaran langsung seperti sering kali dilakukan atau diskusi pelajaran yang dipimpin oleh guru tetapi bisa juga memasukkan presentasi audiovisual. Kedua, tim yang terdiri dari empat atau lima siswa yang mewakili seluruh bagian dari kelas dalam 
hal kinerja akademik, jenis kelamin, ras bdan etnisitas. Ketiga, Kuis. Setelah sekitar satu atau dua periode setelah guru memberikan presentasi dan sekitar satu atau dua periode praktik tim, para siswa akan mengerjakan kuis individual. Keempat, skor kemajuan Individual. Skor individual ini untuk memberikan kepada tiap siswa tujuan kinerja yang akan dapat dicapai apabila mereka bekerja lebih giat dan memberikan kinerja yang lebih baik dari pada sebelumnya. Kelima, rekognisi guru. Tim akan mendapat sertifikat atau bentuk penghargaan yang lain apabila skor rata-rata mereka mencapai criteria tertentu.

b) Teams Games-Tournamnet (TGT). Pada mulanya TGT ini dikembangkan oleh David DeVries dan Keith Edwards, ini merupakan metode pembelajaran pertama dari Johns Hopkins. Metode ini menggunakan pelajaran yang sama yang disampaikan guru dan tim kerja yang sama dengan seperti dalam STAD, tetapi menggantikan kuis dengan turnamen mingguan, dimana siswa memainkan game akademik dengan anggota tim lain untuk menyumbangkan poin bagi skor timnya.

c) Jigsaw II. Jigsaw II adalah adaptasi dari tehnik teka-teki Elliot Aronson (1978). Dalam tehnik ini siswa bekerja dalam anggota kelompok yang sama, yaitu empat orang dengan latar belakang yang berbeda seperti dalam STAD dan TGT. Para siswa ditugaskan untuk membaca bab, buku kecil atau materi lain, biasanya bidang studi sosial, biografi, atau materi-materi yang bersifat penjelasan terperinci lainnya. Tiap anggota tim ditugaskan secara acak untuk menjadi ahli dalam aspek tertentu dari tugas membaca tersebut.

d) Team Accelerated Instruction (TAI). TAI menurut Slavin, (1991) sama dengan STAD dan TGT menggunakan pengunaan bauran kemampuan empat anggota yang berbeda dan member sertifikat untuk tim dengan kinerja terbaik. Namun metode STAD dan TGT menggunakan pola pengajaran tunggal unytuk satu kelas, sementara TAI menggabungkan 
pembelajaran kooperatif dengan pengajaran yang individual. Selain itu, STAD dan TGT dapat diapilkasi pada hampir semua mata pelajaran di tingkat kelas, sementara TAI dirancang khusus untuk mengajarkan matematika kepada siswa kelas 3-6 (atau siswa pada kelas lebi tinggi yang belum siap menerima materi aljabar lengkap). Dalam TAI para siswa memasuki sekuen individual berdasarkan tes penempatan dan kemudian melanjutkan dengan tingkat kemampuan sendiri. TAI dirancang untuk memuaskan kriteria berikut ini untuk menyelesaikan masalah-masalah teoritis dan praktis dari sistem pengajaran individual: (a) dapat meminimalisir keterlibatan guru dalam pemeriksaan dan pengelolaan rutin; (b) guru setidaknya akan menghabiskan separuh dari waktunya untuk mengajar kelompok-kelompok kecil; (c) operasional program tersebut akan sedemikian sederhananya sehingga para siswa di kelas tiga ke atas dapat melakukannya; (d) para siswa akan termotivasi untuk mempelajari materimateri yang diberikan dengan cepat dan akurat, dan tidak akan bisa berbuat curang atau menemukan jalan pintas.

e) Cooperative Integrated Reading and Composition (CIRC). Merupakan program komprehensif untuk mengajarkan membaca dan menulis pada kelas sekolah dasar pada tingkat yang lebih tinggi dan juga pada sekolah menengah (Slavin 1991). Dalam CIRC guru menggunakan novel atau bahan bacaan yang berisi latihan soal dan cerita. Mereka mungkin menggunakan atau tidak menggunakan kelompok membaca, seperti dalam kelas membaca tradisional. Para siswa ditugaskan untuk berpasangan dalam tim mereka untuk belajar serangkaian kegiatan yang bersifat kognitif, termasuk membacakan cerita satu sama lain membuat prediksi mengenai bagaimana akhir dari sebuah cerita naratif saling merangkum cerita satu sama lain, menulis tanggapan terhadap cerita dan melatih pengucapan, penerimaan dan kosa kata.

f) Group Investigation. Group investigation yang dikembangkan oleh Shlomo dan Yael Sharan di universitas Tel aviv, merupakan perencanaan pengaturan kelas yang umum dimana 
para siswa bekerja dalam kelompok kecil menggunakan pertanyaan kooperatif, diskusi kelompok serta perencanaan dan proyek kooperatif (Sharan dan Sharan 1992). Dalam metode ini para siswa dibebaskan membentuk kelompoknya sendiri yang terdiri dari dua sampai enam orang anggota. Kelompok ini kemudian memilih topik-topik dari unit yang telah dipelajari oleh seluruh siswa, membagi topik-topik ini menjadi tugas-tugas pribadi dan melakukan kegiatan yang diperlukan untuk mempersiapkan laporan kelompok.

g) Learning Together. David dan Roger Johson dari Universitas Minnesota mengembangkan model learning together dari pembelajaran kooperatif (Johnson and Smith 1991). Metode yang mereka teliti melibatkan siswa yang dibagi dalam kelompok yang terdiri atas 4 atau 5 kelompok dengan latar belakang berbeda mengerjakan lembar tugas. Kelompokkelompok ini menerima satu lembar tugas dan menerima pujian dan penghargaan berdasarkan hasil kerja kelompok.

h) Complex Instruction. Elizabeth Cohen (1986) dan rekanrekannya di universitas Stanford telah mengembangkan dan melakukan penelitian terhadap pembelajaran kooperatif yang menekankan pada penggunaan proyek berorientasi penemuan, khususnyadalambidangilmupengetahuanilmiah, matematika, dan ilmu sosial. Focus utama dari komplek intruktion adalah pada membangun respek terhadap semua kleampuan yang dimilikipara siswa dan guru menunjukkan baga8imana tiap siswa punya kelebihan dalam sesuatu yang akan membantu keberhasilan kelompok.

i) Stucture Dyadic method (metode struktur berpasangan). Sementara metode-metode kooperatif melibatkan kelompok beranggotakan sekitar empat orang yang memiliki kebebasan tertentu dalam menentukan bagaimana mereka akan bekerja sama, ada peningkatan bagian penelitian dengan metode yang berstruktur lebih tingggi dimana dua orang murid saling mengajarkan. Tradisi kerja laboratorium sudah ada sejak lama, penelitian telah munjukkan bagaimana 
pembelajaran amteri berpasangan, dimana siswqa saling bergantian menjadi guru dan murid untuk mempelajari berbagai macam prosedur atau mencari informasi dari teks dapat menjadi sangat efektif ddalam meningkatkan pembelajaran siswa (Danserau 1998).

\section{E. Peranan Motivasi Belajar dan Pembelajaran Kooperatif Terhadap Prestasi Belajar}

Elliot dkk (1999) menyebutkan ada tiga hal yang dapat diperoleh melalui belajar kooperatif, yaitu motivasi belajar, motivasi untuk saling membantu, dan motivasi untuk berprestasi dalam belajar. Hal ini disebabkan karena dalam metode kooperatif ada actor yang sangat berperan untuk meningkatkan motivasi tersebut yaitu actor komunikasi, kolaborasi dan kooperasi yang kuat, serta diiringi reward sebagai umpan balik. Menurut Djamarah (2002), salah satu fungsi dari motivasi dalam belajar adalah pendorong perbuatan yang akan menimbulkan minat pada diri siswa yang akan mendukungnya untuk melakukan aktivitas belajar. Dikatakan bahwa program belajar koopertif yang diorientasikan pada keberhasilan kelompok berdasarkan keberhasilan individu, memiliki manfaat untuk mencapai tujuan belajar karena berusaha membantu dan mendorong teman-teman kelompoknya untuk bersama-sama berhasil dalam belajar.

Slavin (1991) menyatakan bahwa siswa dalam suasana belajar kooperatif, selain prestasi belajarnya meningkat, juga meningkatkan hubungan baik antar anggota karena mereka dilatih untuk saling toleransi, memahami kelebihan dan kekurangan dirinya sehingga ia akan meminta bantuan penjelasan dari temannya yang dianggap bisa jika merasa belum memahami pelajaran yang diberikan, dan juga diarahkan untuk merespek dan menghargai orang lain, sehingga setiap anggota kelompok akan merasa dihargai. Situasi seperti ini memiliki nilai psikologis yang kuat karena membuat siswa untuk bekerjasama secara kooperatif dengan penuh rasa persaudaraan.

Belajar perlu didukung oleh motivasi yang kuat dan konstan, 
motivasi yang lemah dan tidak konstan akan menyebabkan kurangya usaha belajar, yang pada akhirnya akan berpengaruh terhadap hasil belajar (Sukmadinanta, 2003). Tinggi rendahnya motivasi selalu dijadikan actor-faktor baik buruknya prestasi belajar seseorang, karena motivasi dapat melahirkan prestasi belajar (Djamarah 2002). Ditambahkan Purwanto (2002) juga menyebutkan bahwa salah satu actor yang mempengaruhi prestasi belajar adalah actor-faktor psikologis yang meliputi bakat, minat, kecerdasan, motivasi, dan kemampuan kognitif.

\section{Deskripsi Data}

Data yang diperoleh digunakan sebagai dasar untuk mengetahui hubungan antara motivasi dan belajar kooperatif terhadap prestasi belajar di SD Muhammadiyah Sukonanadi Yogyakarta.

\begin{tabular}{lccccc}
\hline \multicolumn{1}{c}{ Variabel } & $\mathrm{N}$ & Mean & $\mathrm{D}$ & in & ax \\
\hline Motivasi & 8 & 35.68 & .529 & 5 & 3 \\
\hline Kooperatif & 8 & 28.29 & .894 & 1 & 2 \\
\hline Prestasi & 8 & 80.42 & .631 & 2 & 3 \\
\hline
\end{tabular}

Tabel 2: Data Kuantitatif Hasil Penelitian

Tabel 2 menjelaskan mengenai jumlah subjek penelitian (N) sebanyak 38 siswa dengan nilai rerata (mean) untuk variabel motivasi sebesar 35.68, variabel kooperatif sebesar 28.29 dan variabel prestasi sebesar 80.42. Standar deviasi (SD) pada variabel motivasi sebesar 4.529, variabel kooperatif sebesar 2.894 dan variabel prestasi sebesar 5.631. Nilai minimum yang diperoleh oleh subjek penelitian pada variabel motivasi sebesar 25 , variabel kooperatif sebesar 21 dan variabel prestasi memiliki nilai minimum sebesar 72 , sedangkan nilai maximum yang diperoleh subjek untuk variabel motivasi sebesar 43, variabel kooperatif sebesar 32 dan variabel prestasi sebesar 93 .

\section{Hasil Uji Prasyarat}

Uji asumsi normalitas adalah asumsi yang paling dasar sebelum dilakukan uji regresi. Tujuan dilakukan uji asumsi 
normalitas sebaran adalah mengetahui sifat data berdistribusi normal atau tidak normal. Analisis dilakukan terhadap data hasil tabulasi dari skala belajar kooperatif dan motivasi belajar. Uji asumsi normalitas sebaran dilakukan dengan teknik kolmogorov-smirrnov dalam SPSS Release 16.

Kaidah normal yang digunakan untuk uji normalitas adalah jika $\mathrm{p} \geq 0.05$, maka data penelitian terdistribusi normal, sebaliknya jika nilai $\mathrm{p} \leq 0.05$ maka data penelitian tidak terdistribusi normal.

Hasil uji normalitas pada penelitian ini menunjukkan bahwa pada variabel motivasi belajar didapat nilai $\mathrm{Z}$ sebesar 0.818 dengan nilai $\quad p=0.515(p \geq 0.05)$. Pada variabel belajar kooperatif didapat nilai $Z$ sebesar 1,247 dengan nilai $p=0.089$ $(p \geq 0.05$ ) dan variabel prestasi dengan nilai $Z$ sebesar 0,701 dan nilai $\mathrm{p}=0.0709$. Berdasarkan nilai $\mathrm{Z}$ ketiga variable dengan $\mathrm{p} \geq 0,05$ berarti bahwa data penelitian terdistribusi normal.

Sedangkan hasil uji linieritas pada variabel prestasi dengan motivasi diperoleh nilai $F$ sebesar 0,264 dengan $p=0,612$ ( $p>0.05$ ). Hal ini berarti prestasi dengan motivasi tidak memiliki hubungan yang linear. Variabel prestasi dengan kooperatif memiliki nilai $F=0.390$ dengan $p=0.537(p>0.05)$. Dapat disimpulkan bahwa hubungan antara ketiga variabel ini tidak linear. Hasil analisis ini dapat dilihat pada Tabel 4.

\begin{tabular}{lccc}
\hline \multicolumn{1}{c}{ Variabel } & $\mathrm{Z}$ & $\mathrm{p}$ & Keterangan \\
\hline Motivasi Belajar & 0,818 & 0,515 & Normal \\
\hline Belajar Kooperatif & 1,247 & 0,089 & Normal \\
\hline Prestasi & 0,701 & 0,709 & Normal \\
\hline
\end{tabular}

Tabel 3: Hasil Uji Normalitas

\begin{tabular}{cccl}
\hline \multicolumn{1}{c}{ Variabel } & $\mathrm{F}$ & $\mathrm{p}$ & Keterangan \\
\hline Prestasi*motivasi & 0.264 & 0.612 & Tidak linear \\
\hline Prestasi*kooperatif & 0.390 & 0.537 & Tidak linear \\
\hline
\end{tabular}

Tabel 4: Hasil Uji Linieritas 


\section{Hasil Uji Hipotesis}

Berikut ini akan dijelaskan mengenai hasil pengolahan data pengaruh motivasi belajar dengan belajar kooperatif terhadap prestasi belajar. Berdasarkan analisa hasil diketahui koefisien korelasi (R) sebesar 0.133. Hal ini berarti korelasi ganda motivasi dan kooperatif menjadi satu perangkat prediktor sebesar 0.133 . Nilai koefisien korelasi (R) dikonversi dalam nilai F sebesar 0.225 dengan $p=0.799$ ( $p>0.05)$, yang artinya tidak signifikan. Berdasarkan hasil ini, dapat disimpulkan bahwa tidak ada korelasi antara motivasi belajar dengan belajar kooperatif terhadap prestasi belajar.

\section{Pembahasan}

Penelitian yang berjudul Hubungan Antara Motivasi Dan Pembelajaran Kooperatif Terhadap Prestasi Belajar Di SD Muhammadiyah Sukonanadi Yogyakarta ini memperoleh hasil bahwasannya tidak ada hubungan antara motivasi belajar dan pembelajaran kooperatif terhadap prestasi belajar siswa. Dari penelitian ini berdasarkan analisis regresi 2 prediktor, diketahui bahwa tidak ada pengaruh motivasi belajar dengan belajar kooperatif terhadap prestasi belajar. Hasil ini didasarkan pada nilai koefisien korelasi (R) dikonversi dalam nilai $\mathrm{F}$ sebesar 0.225 dengan $\mathrm{p}=0.799(\mathrm{p}>0.05)$. Berdasarkan hasil ini maka hipotesis yang telah diajukan dinyatakan ditolak.

Berdasarkan hasil penelitian yang diperoleh dari penelitian ini, maka dapat dinyatakan bahwa prestasi belajar tidak dapat diprediksi dari motivasi belajar dan metode pembelajaran kooperatif. Dengan kata lain, siswa yang mempunyai motivasi belajar dengan metode belajar kooperatif tidak dapat meningkatkan atau menurunkan prestasi belajar, jadi ada banyak faktor yang dapat mempengaruhi prestasi belajar yang perlu dilakukan penelitian lanjutan. 
F. Catatan Penutup

a) Seorang guru dituntut untuk meningkatkan kompentensi diri dalam memberikan pembelajaran kepada siswa baik dari metode belajar maupun dari sumber belajar.

b) Variasi pembelajaran kepada peserta didik dapat meningkatkan minat siswa dalam belajar.

c) Pembelajaran dengan cooperatif learning merupakan pembelajaran yang dapat menguatkan aspek afektif peserta didik

d) Pembelajaran tidak hanya pada ranah kognitif saja tetapi ada aspek afektif dan psikomotorik yang penting untuk dikembangkan dengan berbagai metode pembelajaran.

e) Motivasi belajar peserta tidak hanya berasal satu faktor saja, misalnya dari metode pembelajaran, akan tetapi banyak faktor yang dapat mempengaruhinya.

\section{DAFTAR PUSTAKA}

De Coco and Crowford. 1977. The Psychology of Learning and Instruction Educational Psychology.

E. Salvin, R. 2009. Cooperative Learning, Teori, Riset dan Praktek. Bandung; Penerbit Nusa Bangsa.

Elliot, et al. 1999. Educatinal Psyichology. Singapore: McGraw-Hill. Hamalik, 0. 2007. Dasar-Dasar Pengembangan Kurikulum. Bandung: Remaja Rosyda Karya.

Hardjito. 1994. Pengaruh Belajar dan Tempat Tinggal terhadap Prestasi Belajar. Yogyakarta.

Kauchak and Eggen. 1997. Educational Psyichology. New Jersey: Practice Hall.

Mahmud, M. 1990. Psikologi Pendidikan Suatu Pendekatan Terapan. Yogyakarta: BPFE Yogyakarta.

McCown. 1997. Educational Psychology Alearning Centered Approach to Classroom Practice. USA: Allyn \& Bacon.

Sukmadinata, Nana Syaodih. 2007. Metode Penelitian Pendidikan. Bandung: Remaja Rosyda Karya. 
Wasito

Santrock, J. 2007. Educatinal Psychology. Texas: McGraw Hill Company Inc.

Slavin, R. 1991. Educational Psyichology: Theory into Practice. New Jersey: Prentice Hall Inc.

Sugandi. 2002. Pembelajaran Pemecahan Masalah Matematika Melalui Model Belajar Kooperatif Tipe Jigsaw. UPI Bandung.

Suryabrata. 1998. Psikologi Pendidikan. Jakarta: PT Raja Grafindo Persada.

Walgito, B. 2002. Pengantar Psikologi Umum. Yogyakarta: Penerbit Andi. 